\title{
An Evaluation of the Prevalence of Substance Abuse among Students of Higher Education Institutions in Benue State, North- Central Nigeria: Implications for Counseling
}

\author{
Anna Onoyase $e^{1}$ \\ ${ }^{1}$ Department of Guidance and Counseling, Delta State University, P. M. B. 1, Abeaka, Delta State, Nigeria \\ Correspondence: Anna Onoyase, Department of Guidance and Counseling, Delta State University, P. M. B. 1, \\ Abeaka, Delta State, Nigeria. E-mail: tinaonoyase@gmail.com
}

Received: April 8, 2019

Accepted: July 9, 2019

Online Published: August 23, 2019

doi:10.5539/ijps.v11n3p39

URL: https://doi.org/10.5539/ijps.v11n3p39

\begin{abstract}
The Investigation was directed towards the prevalence of substance abuse among students of higher education institutions, Benue State North - Central Nigeria. In order to undertake the research, one research question and one hypothesis were formulated to guide the study. The researcher made use of "Prevalence of Substance Abuse among Students Questionnaire" (POSAASQ) to obtain information for the research. The instrument was made up of twenty items. Students responded to substances abused by ticking always (A) 4 points, often (0) 3 points, sometimes (S) 2 points and never $(\mathrm{N}), 1$ point. The reliability coefficient of the instrument was 0.89 while it had content validity and language appropriateness. Six research Assistants were used by the researcher to administer copies of the instrument on the respondents in colleges of education, polytechnics and universities. The mean and standard deviation were used to analyse the data, items $1-20$. The One - Way Analysis of Variance (ANOVA) was used to test the hypothesis. One of the findings revealed that, there is prevalence of substance abuse among students in colleges of education, polytechnics and universities. Another finding showed that, there is significant difference among students in colleges of education, polytechnics and universities in the prevalence of substance abuse. Some of the recommendations include; the government should formulate laws to guide the consumption of different substances in Nigeria so as to prevent abuse, Authorities of Higher Education Institutions should sensitize students on the dangers of substance abuse through the use of posters and handbills.
\end{abstract}

Keywords: prevalence, substance abuse and higher education institutions

\section{Introduction}

Before the 1990s and early part of 1990s, Nigeria and particularly students in Higher Education institutions, enjoyed environments almost devoid of examination malpractice, students' riot, cultism and rape. This may be due to the fact that many of the students may not have been exposed to substance abuse. Substance abuse according to Adewuyi (2010) is related to taking a psychoactive substance or performance enhancing substance for a non-therapeutic non-medical effect. Some of the substances most often associated with this term as listed by Adewuyi include, alcohol, amphetamines, barbituarates, benzodiazepine, cocaine, methaqualone and opium alkaloids. Generally, substances are abused when they are taken continuously without prescription by a medical doctor. Presently, substances appear to constitute a very serious problem in Nigeria for the government and other stakeholders in the lives of youths, as a result of its frequent occurrence. Substance abuse may portend inherent danger, not only to the victims and their families, but the society at large. Drug abuse may be defined as the "arbitrary" over dependence or mis-use of one particular drug with or without a prior medical diagnosis from qualified health practitioners.

Giade (2011), Oshodi, Aina and Onajole (2010) posited that the problem of drug abuse constitutes a great threat to the social, health, economic fabrics of the families society and the nations affected. Increase in the abuse of substances could be due to the availability of such substances and the absence of laws regulating the buying and sale of some of the substances.

\section{Review of Related Literature}

Adewuyi (2010) stressed that substance abuse refers to the use of a particular substance by an individual again and again even when it has not been recommended by a medical doctor. Iliyasu (2015) defined substance abuse 
as one of the behavior disorders that is drawing the attention of every country, state and local government around the globe. Iliyasu further stressed that the most difficult situation which many societies and families found themselves, is the undesirable development that is currently taking place in almost every family set up, whereby, due to psychological, environmental, emotional and other physical forces, youths are lured into abusing substances. Oshodi, et. al. (2010) reported that the desire to experiment and seek abstract solution to problems has been shown to be partly responsible for high prevalence of substance abuse among higher education students.

The United Nations (2016), World Drug Report estimated that one in 20 adults or a quarter of a billion people between the ages of 15 and 64 years used at least one psychoactive drug in 2014. Of these, over 29 million people worldwide suffered from substance use disorders. Yusuf (2010), Aluede, Jimoh, Agwinede and Omoregie (2005) asserted that in many of the higher institutions of learning in Nigeria, there have been incessant students' unrest, riots and cultism, many of which have been directly linked with substance abuse.

Fareo (2012) and Imam (2004) noted that young people are ruining their lives through misuse of drugs. Fareo (2012) and Imam (2004) claimed that a comparison with other third world countries revealed that Nigeria ranked among the highest users of dangerous drugs such as alcohol, tobacco, and cannabis. Adewuyi (2010) opined that there is high rate of suicide in alcoholics and drug abusers. He stressed that the reasons for the increased risk of suicide include the long- term abuse of alcohol and drugs causing physiological distortion of brain chemistry as well as the social isolation. Adewuyi reported that suicide was very common in adolescent alcohol abusers with 1 in 4 suicides in adolescents being related to alcohol abuse. Adewuyi maintained that in the United States of America (USA) alcohol abuse accounted for 30 percent of suicides.

Fayombo and Aremu (2000), Okorodudu and Okorodudu (2004) in their research on the effect of drug abuse on academic performance of some adolescents drug abusers in Ibadan, Nigeria found out that the abuse of marijuana has reached an epidemic level in the present Nigerian society and that drug abuse could lead to reduced academic achievement or even halt one's entire academic process. Enakpoya (2009) investigated drug abuse among secondary school students in Ethiope East Local Government Area, Delta State, Nigeria. Out of the 300 students that participated in the study, 220 were found to be drug abusers while 80 were found to be non abusers. The study also found that alcohol, Librium and marijuana were the most commonly abused drugs in that order. The patent medicine store was the major source of obtaining drug while the main motivator of drug abuse was peer influence. The study revealed that drug abusers frequently beat up junior students and talk rudely to teachers.

Onofa, Adamson, Ighoroje and Majekodunmi (2016) research on the prevalence and pattern of drug abuse among 1,400 students of tertiary institutions in Abeokuta, Ogun State, Nigeria. The researchers found out that alcohol was the most prevalent drug abused with 34 percent. This was followed by Tobacco with 14.4 percent, hypnosedatives with 8.8 percent, cannabis with 6.2 percent, inhalants 2.5 percent and opiates 2.0 percent. Others are cocaine with 1.9 percent, heroin 0.5 percent and amphetamine 0.1 percent. They additionally found significant differences between Christians and other students who belong to other religions in their consumption of alcohol. There was a higher prevalence rate of alcohol use among students whose fathers were dead than those whose fathers were alive. Their finding also showed that the higher the parents' educational level, the more use of alcohol by the respondents.

\section{Definition of terms}

The following terms have been defined operationally;

\section{Prevalence}

This refers to the existence of something and in this study, it is the existence of substance abuse in Higher Education institutions.

\section{Substance Abuse}

This can be defined as the excessive use of legal and illegal drugs for medical and non-medical purposes as well as the consumption of non-edible things.

\section{Higher Education Institutions}

These are post-secondary education institution and they are colleges of education, polytechnics and universities.

\section{Statement of the Problem}

The Educational institutions (including Higher Education Institutions) constitute what make up Nigeria as a system. What happens in Nigeria as a system could affect higher education institution as a sub- system. In 
Nigeria today, there is prevalence of armed robbery, rape, kidnapping, cultism and ritual killings. Higher education institutions are not exempted from these crimes e.g. issues of examination malpractice, cultism, rape and mental problem appear visible. The question that comes to mind is: what is the cause of these crimes? The cause may be attributed to the abuse of certain substances like tramadol, alcohol, cocaine, opium, heroine, tobacco and marijuana etc. as students consume these substances uncontrollably so that they can feel 'high'. Students in this state of euphoria could partake or initiate illegal acts without thinking of their consequences or manifest unusual behavior without the slightest thought of the impact of such actions on people around them. The problem of this research, put in a question form is: what is the prevalence of substance abuse among students of Higher Education Institutions in Benue State North Central Nigeria? The researcher formulated one research question and one hypothesis to guide the investigation.

\section{Research Question}

What is the prevalence of substance abuse among students of higher education institutions in Benue State?

\section{Hypothesis}

There is no significance difference among students in colleges of education, polytechnics and universities on the prevalence of substance abuse.

\section{Research Method and Procedure}

The investigator employed the descriptive survey method in this research. Bryman and Tee van (2005) maintained that this method involves gathering of data concerning the present status of the topic under investigation. The population of the study consists of students from colleges of education, polytechnics and universities in Benue State, North Central Nigeria. The researcher used "Prevalence of Substance Abuse Among Students Questionnaire (POSAASQ) to gather information for the research. The instrument comprised twenty items with a 4 point rating scale: Always (A), 4 points, Often (O) 3 points, Sometimes (S), 2 points and Never (N) 1 point. The instrument had language appropriateness and content validity. It has a reliability coefficient of 0.89 .

The investigator used six research Assistants to administer the instrument on the students in their institutions. 110 copies were administered on colleges of education students, 120 copies of the instrument were administered on the polytechnic students and 163 copies of the instrument administered on university students totaling 393 copies. 100 copies or 90.9 percent were retrieved from the colleges of education, 98 copies or 81.6 percent of the instrument were retrieved from polytechnics and 155 copies or 95.1 percent were retrieved from the universities.

The collation of the data collected from the fieldwork was done by the researcher on the twenty items using mean and standard deviation. The benchmark of 2.50 was chosen for either always, often, sometimes or never for each of the twenty items. The researcher used one way Analysis of variance (ANOVA) to test the hypothesis at 0.05 level of significance. 


\section{Findings}

\subsection{Research Question}

What is the prevalence of substance abuse among students of higher education institutions in Benue State?

Table 1. Mean and standard deviation on the prevalence of substance abuse among students of higher education institutions

\begin{tabular}{|c|c|c|c|c|c|c|c|c|c|c|}
\hline \multirow[b]{2}{*}{$S / N$} & \multirow[b]{2}{*}{ Substance } & \multicolumn{3}{|c|}{$\begin{array}{l}N=100 \\
\text { Colleges of Education }\end{array}$} & \multicolumn{3}{|c|}{$\begin{array}{l}N=98 \\
\text { Polytechnics }\end{array}$} & \multicolumn{3}{|c|}{$\begin{array}{l}N=155 \\
\text { Universities }\end{array}$} \\
\hline & & Mean & SD & Decision & Mean & SD & Decision & Mean & SD & Decision \\
\hline 1 & Tramadol & 2.43 & 1.18 & Sometimes & 2.97 & 0.96 & Sometimes & 3.66 & 0.77 & Often \\
\hline 2 & Alcohol & 3.01 & 0.86 & Often & 3.39 & 0.67 & Often & 3.23 & 0.54 & Often \\
\hline 3 & Iodine & 2.58 & 1.01 & Sometimes & 3.33 & 0.69 & Often & 2.91 & 0.43 & Sometimes \\
\hline 4 & Tobacco & 2.49 & 1.08 & Sometimes & 3.27 & 0.44 & Often & 3.53 & 0.68 & Often \\
\hline 5 & Marijuana & 2.62 & 1.00 & Sometimes & 3.71 & 0.45 & Often & 2.80 & 0.74 & Sometimes \\
\hline 6 & Cocaine & 2.75 & 0.97 & Sometimes & 3.26 & 0.66 & Often & 3.00 & 0.67 & Often \\
\hline 7 & Caffeine & 2.64 & 1.13 & Sometimes & 3.44 & 0.50 & Often & 2.99 & 0.78 & Sometimes \\
\hline 8 & Dry faeces & 2.39 & 0.98 & Sometimes & 3.60 & 0.42 & Often & 3.52 & 0.76 & Often \\
\hline 9 & Glue & 2.71 & 0.96 & Sometimes & 3.09 & 0.29 & Often & 2.61 & 0.59 & Sometimes \\
\hline 10 & $\begin{array}{l}\text { Formaldehyde } \\
\text { (used in } \\
\text { embalming dead } \\
\text { bodies) }\end{array}$ & 2.46 & 1.06 & Sometimes & 3.50 & 0.71 & Often & 3.07 & 0.76 & Often \\
\hline 11 & Librium & 2.45 & 0.95 & Sometimes & 3.17 & 0.48 & Often & 2.81 & 0.88 & Sometimes \\
\hline 12 & Heroine & 2.69 & 0.98 & Sometimes & 3.12 & 0.66 & Often & 3.23 & 0.73 & Often \\
\hline 13 & Amphetamine & 2.72 & 0.94 & Sometimes & 3.20 & 0.82 & Often & 3.09 & 0.95 & Often \\
\hline 14 & Opium & 2.74 & 0.89 & Sometimes & 3.73 & 0.71 & Often & 3.10 & 0.61 & Often \\
\hline 15 & Benzodiazepine & 2.72 & 1.01 & Sometimes & 3.92 & 0.28 & Often & 2.85 & 0.70 & Sometimes \\
\hline 16 & Methaqualone & 2.68 & 0.99 & Sometimes & 3.06 & 0.57 & Often & 3.05 & 0.58 & Often \\
\hline 17 & Phencyclidine & 2.89 & 1.07 & Sometimes & 2.95 & 0.72 & Sometimes & 2.88 & 0.78 & Sometimes \\
\hline 18 & Barbiturate & 2.65 & 1.06 & Sometimes & 3.51 & 0.91 & Often & 3.20 & 0.98 & Often \\
\hline 19 & Paint thinner & 2.46 & 1.15 & Sometimes & 3.07 & 0.90 & Often & 2.78 & 0.88 & Sometimes \\
\hline \multirow[t]{2}{*}{20} & Hashish & 2.10 & 1.05 & Sometimes & 3.29 & 0.69 & Often & 3.04 & 0.92 & Often \\
\hline & Grand mean & 2.61 & & & 3.33 & & & 3.07 & & \\
\hline
\end{tabular}

The result in table 1, revealed that the grand mean of 2.61 from colleges of education indicated the prevalence of substance abuse among students. This means that these students 'sometimes' abuse these substances in order to alter their behaviours. While the grand means of 3.33 from polytechnics and 3.07 from universities showed the prevalence of substance abuse among students. This has revealed that students from both polytechnics and universities often abuse these substances.

Also, the findings in table one revealed that the substances mostly abused in colleges of education are alcohol, phencyclidine and cocaine with means of 3.01, 2.89 and 2.75. Polytechnics, the substances mostly abused include benzodiazepine, opium and marijuana and their means are 3.92, 3.73 and 3.71 respectively. Finally, the substances mostly abused in the universities are tramadol, tobacco and dry faeces with the following means; 3.66 , 3.53 and 3.52 .

\subsection{Hypothesis}

There is no significant difference among students in colleges of Education, Polytechnics and Universities on the prevalence of substance abuse. 
Table 2. One way analysis of variance among students in colleges of Education, Polytechnics and Universities on the prevalence of Substance Abuse

\begin{tabular}{llllll}
\hline Source of variation & Sum of squares & Df & Mean square & $F$ & Sig. \\
\hline Between Groups & 10957.750 & 2 & 5478.875 & 381.410 & 0.000 \\
Within Groups & 5027.683 & 350 & 14.365 & & \\
Total & 15985.433 & 352 & & & \\
\hline
\end{tabular}

Table 2, showed that computed $\mathrm{F}$ - value of 381.410 and a $\mathrm{P}$ - value of 0.000 . Testing the hypothesis at an alpha level of 0.05 , the $p$ - value of 0.000 was less than the alpha level 0.05 . Therefore, the null hypothesis was rejected. This implies that there was significant difference among respondents in colleges of Education, Polytechnics and Universities on the prevalence of substance abuse among students.

\section{Discussion}

One of the findings of this investigation is that, there is prevalence of substance abuse among students in colleges of education, polytechnics and universities. This is because the total grand means of 2.61, 3.33 and 3.07 for colleges of education, polytechnics and universities respectively are higher than the benchmark of 2.50 . This finding is in consonance with Oshodi et. al. (2010) who reported that the desire to experiment and seek abstract solution to problems was partly responsible for high prevalence of substance abuse among higher education students. This finding also agrees with Yusuf (2010), Aluede, et. al. (2005) when they asserted that, in many of the higher institutions in Nigeria, there have been incessant students' unrest, riots and cultism, many of which have been directly linked with substance abuse.

The present research found out that alcohol is one of substances most abused by students in colleges of education, polytechnics and universities. This implies that alcohol abuse cut across all the Higher Education Institutions in Benue State. This finding agrees with that of Onofa, et al. (2016) that alcohol was the most prevalent substance abused by students of tertiary institutions in Abeokuta, Ogun State, Nigeria.

Again the research revealed, that there is prevalence of substance abuse among students of colleges of education, polytechnics and Universities. This is in consonance with Fareo (2012) and Imam (2004) who noted that young people are ruining their lives through misuse of drugs. They also observed that in comparison with other third world countries, Nigerians ranks among the highest users of dangerous drugs such as alcohol and tobacco as in table one, items two and four.

The present investigation found out that, there is significant difference among students in colleges of education, polytechnics and universities in the prevalence of substance abuse. The grand means of 3.33 for Polytechnics, 3.07 for Universities and 2.61 for Colleges of Education clearly reveal the differences in the prevalence of substance abuse. The differences may be due to the substances that were available in the environment where the colleges of education polytechnics and universities were located.

\section{Conclusion}

The conclusion that may be dawn as a result of the findings is that, there is substance abuse among students of higher education institutions in Benue State, North Central Nigeria. This is because the grand means of 2.61, 3.33 and 3.07 for the colleges of education, polytechnics and universities respectively are higher than the benchmark of 2.50 .

\section{Recommendations}

Based on the findings, the followings have been recommended;

1. The government should put in place a law prohibiting the purchase of drugs without doctor's prescription, by the general public (including students).

2. The government should formulate laws guiding the consumption of different substances in Nigeria so as to prevent abuse.

3. The government should establish more hospital rehabilitation centres for substance abusers and the cost of treatment subsidized so that they (victims) can afford it.

4. Authorities of Higher Education Institution should sensitize students on the dangers of substance abuse through the use of posters and handbills.

5. Churches and mosques should sensitize students (their members) during worship, on what constitute substance abuse and its effects on the victims' academics and health. 
6. During matriculation ceremony, new students should be made to sign an undertaking that they will not abuse any substance and that disciplinary action should be meted to them (students) if they do otherwise.

\section{Implications for Counselling}

The followings are the implication fo the study for counsellors:

1. Professional counsellors in Higher Education institutions are to liaise with the Nigerian Medical Association (NMA) and the National Agency for Food and Drug Administration and Control (NAFDAC) in order to give lectures on substance abuse and its hazards, to students on an annual basis.

2. Counsellors in collaboration with School Authorities are to refer students identified as substance abusers to rehabilitation centres for necessary assistance.

3. Professional counsellors are to organize seminars for academic and non-academic staff on how to identify unusual behaviours among students which may have been caused by substance dependence and refer such students to counsellors for psychological assistance.

\section{References}

Adewuyi, T.D.O. (2010). Psychological perspectives of peer group and drug abuse among undergraduate in Lagos State University. Official publication of the Counselling Association of Nigeria (CASSON).

Aluede, O, Jimoh, B., Agwinede B.O. \& Omoregie, E. O. (2005). Students unrest in Nigerian universities; looking back and forward, Journal of Social Sciences, 10, 17 - 22. https://doi.org/10.1080/09718923.2005.11892454

Bryman, A. \& Teevan, J. J. (2005). Sexual research and methods: Canadian edition. Canada Oxford University Press.

Enakpoya, E. (2009). Prevalence of drug abuse among Nigerian adolescents; Implications for counseling, Journal of Counselling Association of Nigeria (CASSON), 26(2), 155-164.

Fareo, D. O. (2012). Drug abuse among Nigerian adolescents: strategies for counselling. The Journal of International Social Research, 20, 5-2.

Fayombo, G. A. \& Aremu, S. (2000). Drug education and its effects on educational performance of some adolescent drug abusers in Ibadan, The Counsellor, 18(5), 378 - 387.

Giade, A. (2011). How Nigeria's Latest Drug Abuse Defies Legislation. Daily Trust Newspaper June 30. Retrieved

from http://www.dailytrust.com.ng/daily/old/index.php/feature/42852-how-nigerias-latest-drug-abuse-defies-legi slation

Iliyasu, A. (2015). "An assessment of the prevalence of drug abuse among in- mates of Kiru Reformation Institute in Kano State Nigeria" Counselling Association of Nigeria (CASSON) Ed. By Adegoke, A. A., Akuede, O. \& Eweniyi, G.

Imam, F. Z. (2016). Drug/ substance abuse among students of Kaduna Polytechnics. International Journal of psychiatry, 1(1),1-6.

Imam, F.Z. (2004). Drug/substance abuse among students of Kaduna Polytechnics cited in Onofa L. U. Adamson, T. Ighonoje, M, \& Majedunmi, M(2016). International Journal of Pschyiatry, 1(1), 1-6.

Lakhanpal, P. \& Agrihotril, A.K. (2007). Drug Abuse an International ZZProblems. A Short Review with Special Reference to African Continent. Journal of Medicine and Toxicology.

Okorodudu, R. \& Okorodudu, G. N. (2004). An overview of conduct problems of the Nigerian child, Journal of Nigerian Society for Educational Psychologies (NICEP), 76- 83.

Onofa, H. U. Adamson, T, Ighoroje, M \& Majekodunmi, M. (2016). Prevalence and patterns of drug abuse among students of tertiary institutions in Abeokuta, Ogun State, Nigeria, International Journal of Psychiatry, 1(1),1-6.

Onofa, L. U., Adamson, T., Ighoroje, M. \& Majekodunmi, M. (2016). International Journal Psychiatry, 1(6).

Oshodi, O., Aina, O. Onajole, A. (2010). Substance use among secondary school students in an urban setting in Nigeria: Prevalence and associated factors. African Journal of Psychology, 13(1), 52-57. https://doi.org/10.4314/ajpsy.v13i1.53430 
UNO Crime. (2016). World drug report 2016 United Nations Publication.

Yusuf, F. A. (2010). Factors influencing substance abuse among undergraduate students in Osun State, Nigeria. African Research review, 4(4). https://doi.org/10.4314/afrrev.v4i4.69233

\section{Copyrights}

Copyright for this article is retained by the author(s), with first publication rights granted to the journal.

This is an open-access article distributed under the terms and conditions of the Creative Commons Attribution license (http://creativecommons.org/licenses/by/4.0/). 